\title{
Okuma Anlama Düzeyleriyle Özyeterlik Algısı Arasındaki İlişki Bağlamında Ortaokul Öğrencilerinin Görünümleri
}

\author{
Views of Secondary School Students in the Context of Relationship \\ between Self-Efficacy and Reading Comprehension Levels \\ Hakan ÜLPER* ${ }^{*}$ Ayşe Nur ŞİRIN***
}

• Geliș Tarihi: 26.11 .2018 • Kabul Tarihi: 19.02.2019 • Çevrimiçi Yayın Tarihi: 03.07.2019

\begin{abstract}
Öz
Okuma, bilişsel olduğu kadar duyuşsal bir süreci de kapsamaktadır. Duyuşsal boyutun alt ulamlarından birisi olan özyeterlik algısı, okuma sürecinde anlama ve anlamlandırmayı etkilemektedir. $\mathrm{Bu}$ çalışmanın amacı, okuma özyeterlik algısı ile okuduğunu anlama becerisi arasındaki çok boyutlu ilişki çerçevesinde alanyazına farklı örneklemler üzerinde gerçekleştirilmiş araştırma bulgularını kazandırarak alanyazının derinleşmesine katkı sağlamaktır. Bu bağlamda Antalya ili evren olarak belirlenmiştir. Bu evrenden tesadüfi olarak belirlenen 1033 öğrencinin oluşturduğu örneklemden veriler toplanmıştır. Okur özyeterlik ölçeği ve okuma anlama testi soruları aracılığı ile toplanan veriler SPSS programına yüklenerek çözümlenmiştir. Verilerin işlenmesinde Spearman Sıra Farkları Korelasyon Katsayısı hesaplanmıştır. Ortaya çıkan sonuca göre 8. Sınıf öğrencilerinin özyeterlik algısının yüksek olduğu tespit edilmiştir. Özyeterlik algısı ve okuma anlama arasındaki ilişki de orta düzeyde ve anlamlı pozitif bir ilişki şeklinde bulgulanmıştır. Elde edilen bulgular alanyazındaki ilgili araştırmalarla tartışılarak sonuç bölümünde sunulmuştur.
\end{abstract}

Anahtar sözcükler: çıkarımsal kavrama, yüzeysel kavrama, özyeterlik.

Atıf:

Ülper, H., ve Şirin, A. N. (2020). Okuma anlama düzeyleriyle özyeterlik algısı arasındaki ilişki bağlamında ortaokul öğrencilerinin görünümleri. Pamukkale Üniversitesi Eğitim Fakültesi Dergisi,48 , 1-14. doi: 10.9779/pauefd.487556

\footnotetext{
* Prof. Dr. MAKÜ, Eğitim Fakültesi, ORCID: 0000-0002-7067-599X

** YL Öğrencisi, MAKÜ, Eğitim Bilimleri Enstitüsü, ORCID: 0000-0002-8802-9988
} 


\begin{abstract}
Reading includes an affective process as well as cognitive one. As one of the sub-categories of affective dimension, the perception of self-efficacy has an effect upon comprehension and interpretation in the process of reading. The aim of this study is to contribute to deepen the literature by bringing the findings of research that is practiced on different samples within the frame of dimensional relationship between the perception of reading self-efficacy and reading comprehension skill. In this context the city of Antalya is defined as population. Data are collected from the samples of 1033 students defined circumstantially. Data that are gathered by means of reader self-efficacy scale and reading comprehension test questions, are loaded to SPSS program and analyzed. In the process of data, Spearman's Rank Correlation Coefficient is calculated. According to the result, it is ascertained that perception of self-efficacy of 8th grade students is high. Relationship between perception of self-efficacy and reading comprehension is also discovered as medium-level and significant positive correlation. Acquired findings are presented at the conclusion part by being discussed with the related researches in the literature.
\end{abstract}

Keywords: inferential grip, superficial grip, self-efficacy.

\title{
Cited:
}

Ülper, H., \& Şirin, A. N. (2020). Views of secondary school students in the context of relationship between self-efficacy and reading comprehension levels. Pamukkale Üniversitesi Eğitim Fakültesi Dergisi, 48, 1-14. doi: 10.9779/pauefd.487556 


\section{Giriş}

Kişilerin davranış ve düşüncelerini neyin kontrol ettiği, olaylar ve gelişmeler karşısından nasıl bit tutum içinde olacaklarını nelerin belirlediği ya da yönlendirdiği, bir eylemi gerçekleştirirken ya da gerçekleştirmekten kaçınırken etkili olan etmenlerin neler olduğu, bu süreçte gerekli olan enerjiyi ve isteği sağlayan içsel gücün ne olduğu gibi birçok konu bilişsel ve bedensel işlemlerin dışında kalan duyuşsal boyutla ilgilidir. Bu duyuşsal boyut içinde yer alan ve son derece önemli ve yaygın durumda olan konu başlıklarından biri özyeterlik inancıdır.

Özyeterlik, bir kişinin bazı özel amaçlara ulaşmak için gerekli olan becerilere sahip olduğuna ilişkin algısıdır. Algılanan özyeterliği yüksek olan kişiler düşük olan kişilere göre daha çok denemekte, başarılı olmakta ve bir etkinlikte daha uzun süre sabırla yer alabilmektedir. Ancak özyeterlik algısı ile kişinin o alandaki özyeterlik becerileri örtüşmeyebilir. Bireyler bazen gerçek becerilerine eşit, bazen gerçek becerilerinden düşük, bazen de yüksek özyeterlik algısına sahip olabilir (Tracey ve Morrow, 2017).

Öğrencilerin kendi öğrenmelerini düzenleme ve akademik etkinlikleri denetleme konusundaki yeterlik algıları isteklerini, güdülerini ve akademik başarılarını belirler. Psikolojide zekâ akademik başarının güçlü bir yordayıcısı olarak görülmektedir. Akademik performans açısından zekâ ve özyeterliğin ortak katkısı test edildiğinde özyeterliğin akademik performansa güçlü ve bağımsız bir biçimde katkı sağladığı saptanmıştır. Bu durum ne denli yetenekli olunduğunun değil aynı zamanda yetenekli olduğunuza ne denli inanmakta olduğunuzun da önemli olduğuna işaret etmektedir (Bandura, 1993; Pajares, F., 2005).

Yukarıda da belirtildiği gibi özyeterlik sahibi olmak önemlidir, ancak başarı üzerindeki tek belirleyici değildir. Özyeterlik yanında beceri, bilgi, beklenti ve algılanan değer olguları da başarıda belirleyici role sahiptirler. Gerekli beceri ve bilgi eksikse sadece yüksek yeterlik sahibi olmak, yetkin performans sergilemede yeterli gelmeyecektir. Yine sonuçla ilgili beklentiler de önemlidir çünkü öğrenciler olumsuz sonuçlanacağına inandıkları etkinlikleri gerçekleştirmek istemezler benzer bir biçimde değerli bulmadıkları etkinliklerin de içinde yer almak istemezler (Akt. Schunk, 2003).

$\mathrm{Bu}$ bakımdan öğrenmede yeterlilik, becerileri ve aynı zamanda becerileri etkili bir biçimde kullanmaya yönelik özyeterlik inançlarını gerektirmektedir. Özyeterlik, insanların belirli öğrenme ile ilgili görevleri yerine getirmek için gerekli olan eylemleri organize etme ve yürütme becerilerini oluşturan yargıları temsil eder. Bu kararlar genellikle, öğrencilerin belirli görevleri yerine getirip üstlenemeyecekleri konusunda kendilerine olan güven düzeylerini ölçmeleri ile değerlendirilir (Bkz. Chapman ve Tunmer, 2003).

Yukarıda genel bir çerçeve içerisinde verilen özyeterlik algısı okuma becerileri özyeterliliği zemininde ele alındığı zaman, kişinin yetkin okuyabilme ve zor metinleri anlayabilme kapasitesine ilişkin inancı olarak tanımlanabilir. Okuma özyeterliği şunları içerir: İyi okur olduğuna inanma, okumada kendine güvenme, okumada stratejiler kullanma (Guthrie vd., 2006).

Özyeterlik algısının etkisi üzerine çok sayıda araştırma yapılmıştır. Mills, Pajares ve Herron (2006) ilgili birçok araştırma sonucuna gönderimde bulunarak öğrencilerin kendi akademik potansiyellerine ilişkin algılarının akademik davranışlar ve performansları üzerinde 
birçok açıdan güçlü bir etkisinin olduğunu belirtmektedir. Örneğin özyeterlik algısı yüksek öğrenciler zorlu görevleri üstlenme, dirençli olma, öğrenme stratejilerini kullanma, kaygı düzeyi düşük olma, akademik performanslarını doğru olarak değerlendirme gibi noktalarda daha iyi bir görünüm sergilemektedirler. Buna karşın düşük öz-yeterlik düzeyinde olan öğrenciler ise, az çaba harcamakta, dirençsiz olmakta ve akademik görevleri tamamlamada isteksiz davranabilmektedirler.

Akademik davranış ve performansla ilgili olarak böyle bir durumun varlığı benzer bir biçimde dil öğrenmeyle ilişkili alanda da gözlemlenebilmektedir. Mills, Pajares ve Herron (2006) tarafından katılımcılarını ABD'nin güney doğusundaki bir üniversitede üçüncü ve dördüncü dönem Fransızca derslerine kayıtlı 95 üniversite öğrencisinin oluşturduğu öğrencilerle yapılan araştırma bulgularına göre katılımcıların Fransızca özyeterlik algılarıyla Fransızca okuma becerileri arasında pozitif yönde bir ilişki bulunmaktadır. Yabancı dil öğretimi ile ilgili bir diğer çalışmada da benzer bir sonuca ulaşılmıştır. Ghonsooly ve Elahi (2010), birinci dili Farsça olan öğrencilerle yaptığı çalışmada İngilizce öğrenme bağlamında yüksek okuma özyeterliğine sahip öğrencilerin, düşük olanlara göre okuma-anlamada daha yüksek puanlar aldıklarını ortaya koymuştur. Birinci dili Farsça olan ve yabancı dil olarak İngilizce öğrenen öğrencilerin özyeterlikleriyle okuma becerileri arasındaki ilişkiyi belirlemeyi amaçlayan diğer çalışmaların bulguları da bu iki olgu arasında olumlu yönde bir ilişkinin olduğunu göstermektedir (Bkz. Ghabdian ve Ghafournia, 2016; Naseri ve Ghabanchi, 2014). Anadili Türkçe olan öğrencilerin durumuyla ilgili çalışmada ise 414 öğrencinin İngilizceyle ilgili algıladıkları öz yeterlik desteğiyle okuma-yazma $(r=0.31, p<0.01)$ öz yeterlikleri arasında pozitif yönlü ve anlamlı bir ilişki belirlenmiştir (Kanadlı ve Bağçeci, 2015).

Bununla birlikte Shell, Murphy ve Bruning (1989), 153 öğrenci ile gerçekleştirdiği araştırmalarında birinci dil bağlamında da özyeterlik algısı ile öğrencilerin birinci dil okuma başarıları arasındaki ilişkiye dikkat çekmektedir. Bu çerçeve içerisine girecek diğer çalışmaların sonuçları da benzer niteliktedir. Örneğin Mucherach ve Yoder (2008), okuma özyeterliliğinin ortaokul çocuklarının okuma testinden aldıkları puanları yordamakta olduğunu bulmuşlardır. Zimmerman (2000) araştırmasında öğrencilerin kendi okuma yeterliklerine ilişkin inançlarının düşük olması durumunda bu öğrencilerin zorlu okuma etkinliklerinden uzak durma eğiliminde olduklarını bulgulamışlardır.

Diğer yandan özyeterlik, içsel ve dışsal güdü gibi, okuma güdüsünün de ulamlarından biridir. Kuramsal çerçevede okuma güdüsünün öğrencilerin okuma becerilerine etkisi açıktır. Wigfield ve Guthrie (1995) tarafından geliştirilen Okuma Güdüsü Sormacası (Motivation for Reading Questionnaire) öğrencilerin aynı zamanda özyeterliklerini de içeren maddelerden oluşan bir boyuta sahiptir. Bu ölçme aracı kullanılarak yapılan birçok çalışmanın bulguları, ilköğretim öğrencilerinin okuma özyeterlikleri ve akademik başarıları arasında sürekli bir ilişki olduğuna işaret etmektedir (Mucherah ve Yoder, 2008).

Yukarıdaki çalışmaların gösterdiği gibi, farklı diller üzerinde gerçekleştirilmiş olan ilgili birçok araştırma sonucu, okumaya ilişkin öğrencilerin sahip oldukları olumlu inançların okuma becerisi üzerine olumlu etkisi olduğunu ortaya koymaktadır. Buna karşın alanyazında bu görünümden daha farklı sonuçların da ortaya çıktığı araştırmalarla karşılaşmak olanaklıdır. Örneğin Solheim'e (2011) göre öğrencilerin okuma özyeterlikleri ile okuma puanları arasında olumlu yönde bir ilişki olmasına, okumada öz-yeterlik düzeyi düşük olan öğrenciler için okuma 
öz-yeterlik algısı okuma anlama becerisi ölçümünün çoktan seçmeli olarak yapılması durumunda önemli bir olumlu yordayıcısı olmasına karşın yapılandırılmış soru-yanıt puanlarının önemli bir yordayıcısı değildir.

Yine özyeterlik, sözcük okuma ve okuduğunu anlama arasındaki ilişkiyi inceleyen Carol ve Fox (2017), 179 öğrenci üzerinden gerçekleştirdiği çalışmasında okuma özyeterliği ile sözcük okumanın ilişkili olduğunu buna karşın okuduğunu anlamanın ilişkili olmadığını bulgulamıştır. Benzer bir biçimde Corkett, Hatt ve Benevides, (2011), 122 altıncı sınıf öğrencisinin okuryazarlığa ilişkin özyeterlik algılarının okuryazarlık yeteneği ile ilişkili olmadığını bulgulamıştır.

Yukarıda ilgili alanyazına göre verilen araştırmaların bulguları, bir yandan özyeterlik ve okuma becerileri arasında olumlu yönde ve anlamlı bir ilişkinin olduğunu, diğer yandan ise belli ölçütlerde olduğunu ya da olmadığını göstermektedir. Bu sonuçlara göre bu iki kavram arasında tutarlı bir ilişkinin olduğunu kesin olarak söyleyebilmek olanaklı görünmemektedir. Burada örneklem grubu, anadili öğretimi, yabancı dil öğretimi, anadilin ne olduğu gibi birçok değişkenin etkili olma olasılığı oldukça yüksek görünmektedir. Bu bağlamda farklı bir dil olarak "Türkçe üzerinde benzer bir durum mu yoksa farklı bir durum mu vardır?" sorusu yanıt aranması gereken önemli bir soru durumuna gelmektedir.

Bu soruya yanıt aramak amacıyla bakılacak olan Türkçe alanyazında çok sınırlı sayıda çalışmanın olduğu dikkat çekmektedir. Bu çalışmalar kendi içerisinde iki ayrı boyut biçiminde ayrıştırılabilir. Birinci boyuttaki çalışmalar okuma özyeterlik ölçeğinin geliştirilmesiyle ilgilidir (Epçapan ve Demirel, 2011; Karabay, 2013; Ülper, Yayl1, Karakaya, 2013). İkinci boyuttaki çalışmalar ise öğrencilerin okuma özyeterliklerine ilişkin çeşitli açılardan görünümlerini ve okuma özyeterliği algısıyla okuma becerisi ve tutumu arasındaki ilişkiyi ortaya koymayı amaçlamaktadır. Bu çerçevedeki birçok çalışmada (Öztürk, 2015; Uçgun, 2014) farklı sınıf düzeyindeki ortaokul öğrencilerinin okur öz yeterliklerinin nasıl olduğu ve bazı değişkenler açısından anlamlı farklılık gösterip göstermediğine ilişkin araştırma bulgularını görmek olanaklıdır. Eyüp ve Uzuner Yurt (2016) ise araştırmalarında ortaokul öğrencilerinin okuma tutumları ile okuduğunu anlama öz yeterlikleri arasında pozitif yönde anlamlı bir ilişki bulunmuşlardır.

Doğrudan okuma becerisi üzerine odaklanan çalışmalara bakıldığı zaman Yabancı dil olarak Türkçe öğrenmekte olan öğrencilerin anlama başarısı ve okuma becerisi öz yeterlik algıları arasındaki ilişkiyi araştıran Erdem, Altunkaya ve Ateş (2017) bu iki olgu arasındaki ilişkin çok zayıf, pozitif yönde ve anlamlı olduğunu bulgulamışlardır. Bu çalışmanın bir benzerini anadili olarak Türkçe öğrenen ortaokul öğrencileriyle gerçekleştiren Altunkaya (2018), öğrencilerin okur özyeterlik algı düzeylerin düşük olduğunu ve bunun da okuduğunu anlama düzeyini azalttığını saptayarak iki olgu arasındaki ilişkiye dikkat çekmektedir.

İnnalı ve Aydın (2014) tarafından yapılan araştırmada okul puanı pekiyi ve iyi olan öğrencilerin okur öz yeterliklerinin de yüksek olduğu saptanmıştır. Yine önceki yıl Türkçe dersi başarı durumuna göre okur öz yeterliklerinin de artış gösterdiği görülmüştür. Okumanın diğer derslerde olduğu gibi Türkçe dersi başarısında da başat rolü dikkate alınınca bu bulguların açık bir biçimde öğrencilerin okur özyeterlik algılarıyla okuma becerileri arasındaki ilişkiye işaret ettiği görülecektir. 
Tüm bu olumlu ilişkiye işaret eden araştırmalara karşın Ürün Karahan (2017) tarafından Kafkas Üniversitesi Eğitim Fakültesi Türkçe Eğitimi Bölümü öğrencileriyle yapılan çalışmada, Türkçe öğretmeni adaylarının okur öz yeterlik algılarının okuduğunu anlama düzeyleri ile arasında anlamlı bir ilişki olmadığı tespit edilmiştir. Dolayısıyla Türkçe okuma becerisi üzerine az sayıdaki çalışmaların bulguları açık ve tutarlı bir biçimde okuma özyeterliği ile okuduğunu anlama arasında bir ilişki olduğuna işaret etmekte iken bir çalışmanın sonucu okuma özyeterliği ile okuduğunu anlama arasında bir ilişki olmadığına işaret etmektedir.

$\mathrm{Bu}$ çalışmaların sayıca çok sınırlı olması ve bu denli sınırlı sayıda çalışmaya dayanarak bir yargıya varmanın güçlüğü dikkate alınınca yine bu sınırlı sayıdaki çalışmaların farklı değişkenler, farklı örneklemler ve farklı ölçme araçları içeriyor olması dikkate alınınca bu bağlamda Türkçe eğitimi ortamlarına yeterli alanyazın desteği sağlayabilmek için daha çok sayıda araştırmaya duyulan gereksinim açıktır.

Okumayı açıklayan çeşitli kuramlara göre okuma, sözcük okuma, harf-ses bilgisi, doğru okuma ve otomatik okuma alt ulamlarından oluşan sözcük okuma ve sözcükleri, tümceleri ve metni anlama becerisine gönderimde bulunan ve sözcüğün anlamını etkinleştirme, tümceleri anlama, çıkarım yapma, kavramayı denetleme ve metin yapısını anlama alt ulamlarından oluşan kavrama (language comprehension) ana ulamlarından oluşur (Oakhill, Cain ve Elbro, 2015). Metinlerdeki bilgiler sadece metin yüzeyinde değildir. Okuyucular metindeki adılları ve bu adılların gönderimde bulunduklarını anlamalıdırlar; cümlelerin birbirleriyle nasıl ilişkili olduğunu çıkarmalıdırlar ve cümlecikler, paragraflar ve bölümlerin ana konuyla ilişkisini kurabilmelidir. Bunların yanında metni tam olarak anlamak için okurun artalan bilgisini metnin konusuyla ilişkilendirebilmesi gerekir. Bu da çıkarımsal ve yorumsal işlemlemeler gerektirir (Caccamise, Snyder ve Kintsch, 2008).

Çıkarımsal işlemlemeler metinde açıkça verilen bilginin ötesine geçmeyi, var olan bilgileri metindeki bilgiler aracılığıyla yorumlamayı, metindeki farklı tümceler ve düşünceler arasında yeni bağlantılar kurmayı, metindeki bilgiyi yeni bir probleme uygulamayı gerektirir. Dolayısıyla yazılı metnin kavranmasıyla ilişkili her bir işlem farklı düzeyde bilişsel işlemleme ve farklı bilgi kaynaklarının kullanımını gerektirir (Akt. Ülper, Çetinkaya, Bayat, 2017). Bu bakımdan okuma anlama tek boyutlu değildir ve alan yazında metni kavrama genellikle yüzey (literal) ve çıkarımsal olmak üzere ikiye ayrılır (Ülper, 2010). Bu nedenle özyeterlik olgusunun okuma anlama ile ilişkisini araştırırken okuma anlamanın farklı boyutlarıyla ilişkisinin ayrı ayrı araştırılması gerekmektedir.

Alanyazındaki araştırmaların okuma anlamayı tek boyutlu olarak ele almış olmaları nedeniyle alanyazında okur özyeterlik algısının farklı okuma düzeyleriyle ilişkisine henüz değinilmemiştir. Bu nedenle söz konusu araştırmamızın temel amacı da okuma özyeterlik algısı ile okuduğunu anlama becerisi arasındaki çok boyutlu ilişki çerçevesinde alanyazına farklı örneklemler üzerinde gerçekleştirilmiş araştırma bulgularını kazandırarak alanyazının derinleşmesine katkı sağlamaktır. Araştırmamızın problem tümcesi "Öğrencilerin okuma özyeterlik algıları ile okuma-anlama becerileri arasında ilişki var mıdır?” biçimindedir. Alt problemleri ise şöyledir:

1. Öğrencilerin okuma özyeterlik algıları ile yüzey metin sorularından aldıkları puanların görünümü nasıldır? 
2. Öğrencilerin okuma özyeterlik algıları ile çıkarım sorularından aldıkları puanların görünümü nasıldır?

3. Öğrencilerin okuma özyeterlik algıları ile yüzey metin sorularından aldıkları puanları arasında bir ilişki var mıdır?

4. Öğrencilerin okuma özyeterlik algıları ile çıkarım sorularından aldıkları puanları arasında bir ilişki var mıdır?

\section{Yöntem}

Bu çalışma ortaokul 8. sınıf öğrencilerinin okuma özyeterlik algıları ile yüzey metin ve çıkarım sorularından aldıkları puanlar arasındaki ilişkiyi belirlemek için tasarlanan betimsel bir araştırmadır.

\section{Evren Örneklem}

Araştırmanın evreni olarak Antalya ilinde bulunan devlet ortaokullarının 8. sınıflarında eğitim öğretim yaşamını sürdüren öğrenciler oluşturmaktadır. Örneklem olarak bu öğrencilerinden 1033'ü tesadüfi örnekleme yöntemine göre seçilmiştir. Bu seçimde ulaşılabilirlik, uygulamaya gönüllü olarak katılma, uygulama için öğretmenlerin uygun olması gibi değişkenler de dikkate alınmıştır. Bu öğrencilerin 537 si yani \% 52'si kız 496'sı yani \%48'i erkektir. Bunun yanında öğrencilerin 343 ' ü $(\% 33,2)$ alt düzey, 599'u (\%58) orta düzey ve 91 'i $(\% 8,8)$ üst düzey sosyo ekonomik bölgelerdendir.

\section{Çalışmada Kullanılan Ölçme Araçları Okur özyeterlik ölçeği}

Verileri toplamak için iki ayrı ölçme aracı kullanılmıştır. Bunlardan birincisi Okur Özyeterlik Ölçeğidir. Ülper, Yaylı ve Karakaya (2013) tarafindan geliştirilen bu ölçek 36 maddeden oluşan Likert tipi bir ölçektir ve tek boyutludur. Ölçeğin tarafımızdan yapılan uygulamasındaki veriler üzerinden yapılan Açımlayıcı Faktör Analizinde de tek boyutlu olduğu görülmüştür. Ölçeğin Alfa Güvenirlik katsayısı ise ,948 olarak bulunmuştur.

\section{Okuma-anlama testi}

Okuma-Anlama Testi, Ülper, Çetinkaya ve Bayat (2016) tarafindan geliştirilmiştir. Bu test 11 çoktan seçmeli, 3 boşluk doldurma ve 6 doğru-yanlış ve 8 açık uçlu olmak üzere toplam 28 sorudan oluşmaktadır. Bu testteki tüm sorular çıkarım gerektiren ve çıkarım gerektirmeyen yani yüzey metin soruları olarak iki ana ulama ayrılmaktadır. Yüzey metin sorularına ilişkin Alfa Güvenirlik Katsayısı .701; çıkarım sorularına ilişkin Alfa Güvenirlik Katsayısı ise .677 olarak bulunmuştur.

\section{İşlem}

Verilerin toplanabilmesi için Antalya Milli Eğitim Müdürlüğünden gereken izinler alınmış ve verilerin toplanmasına bu izinlerin alınmasından sonra başlanmıştır. Verilerin toplanması için önce okuma anlama testi uygulanmış 1-2 hafta sonrasında ise özyeterlik ölçeği uygulanmıştır. Toplanan veriler SPSS 22 programına girilerek işlenmiştir. Verilerin çözümlenmesinde Spearman Sıra Farkları Korelasyon Katsayısı hesaplanmıştır. Bunu yapmadan önce ön 
gereklerin karşılanıp karşılanmadığına bakılmış ve değişkenlerin normal dağılım göstermediği ama aralarında doğrusal bir ilişki olduğu görülmüştür.

\section{Bulgular}

Birinci ve ikinci araştırma sorusu bağlamında "Öğrencilerin okuma özyeterlik algıları ile yüzey metin ve çıkarım sorularından aldıkları puanların görünümü” Tablo 1'de sunulmaktadır.

Tablo 1. Öğrencilerin Okuma Özyeterlik Algıları ile Yüzey Metin ve Çıkarım Sorularından Aldıkları Puanların Görünümü

\begin{tabular}{lcrrrr}
\hline & $\mathrm{N}$ & En Düşük & En Yüksek & Ortalama & Std. Sapma \\
\hline Özyeterlik & 1033 & 52 & 175 & 145 & 20.71308 \\
Ç1karım & 1033 & .00 & 19.00 & 11 & 3.33012 \\
Yüzey Metin & 1033 & 1.00 & 14.00 & 10 & 2.62950 \\
\hline
\end{tabular}

Özyeterlik ölçeğinden alınabilecek en düşük puan 36 iken en yüksek puan 180'dir. Öğrenciler özyeterlik ölçeğinden 52-175 arası puan almışlardır. Ortalama puanları ise 145 olarak bulunmuştur. Buna göre öğrencilerin aldığı ortalama puanlara bakarak özyeterlik algılarının yüksek düzeyde olduğu söylenebilir.

Okuduğunu anlama testinin çıkarım sorularından alınabilecek en düşük puan o iken en yüksek puan 22 'dir. Yine yüzey metin sorularından alınabilecek en düşük puan 0 iken en yüksek puan 14'tür. Buna göre öğrencilerin aldıkları çıkarım puanlarının dağılımı 0-19 arasında; yüzey metin sorusu puanlarının dağılımı 1-14 arasındadır. Öğrenciler arasında yüzey metin sorularının tamamını doğru yanıtlayan öğrenci yer alırken çıkarım sorularının tamamını doğru yanıtlayan öğrenci yer almamıştır. Bununla birlikte çıkarım puanlarının ortalaması 22 puan içinden 11 iken yüzey metin puanlarının ortalaması ise 14 puan içinden 10'dur. Buna duruma göre öğrencilerin yüzey metin sorularını yanıtlamada daha başarılı oldukları buna karşın çıkarım sorularını yanıtlamada ise daha başarısız oldukları dikkat çekmektedir. Çıkarım sorularındaki başarı durumları ortalama düzeyde iken yüzey metin sorularındaki başarı düzeyleri daha yüksek görünmektedir.

Üçüncü ve dördüncü araştırma sorusu bağlamında "Öğrencilerin okuma özyeterlik algıları ile yüzey metin ve çıkarım sorularından aldıkları puanları arasında bir ilişki var mıdır?" sorusuna ilişkin görünüm Tablo 2'de sunulmaktadır.

Tablo 2. Puanlar Arası İlişsileri Gösteren Spearman Sıra Farkları Korelasyon Tablosu

\begin{tabular}{llccc}
\hline & 1 & 2 & 3 \\
\hline Özyeterlik & - & $.261^{* *}$ & $.352^{* *}$ \\
Çıkarım & & - & $.527^{* *}$ \\
Yüzey Metin & & & \\
\hline
\end{tabular}

$* * \mathrm{p}<.01$

Öğrencilerin özyeterlik algılarıyla yüzey metin ve çıkarım sorularını yanıtlama becerileri arasında bir ilişki olup olmadığını ortaya koymak amacıyla yapılan Spearman Sıra Farkları Korelasyon testi sonucuna göre özyeterlik algısı ile hem yüzey metin hem de çıkarım sorularını yanıtlama arasında 0.01 düzeyinde anlamlı bir ilişki olduğu ortaya çıkmıştır. 
Özyeterlik algısıyla çıkarım sorularını yanıtlama arasındaki ilişki .261 olarak bulunmuştur. Bu ilişki düşük düzeyde bir ilişki olarak yorumlanabilir. Buna karşın özyeterlik algısıyla yüzey metin sorularını yanıtlama arasındaki ilişki .352 olarak bulunmuştur. Bu ilişki orta düzeyde bir ilişkinin varlığına işaret etmektedir.

\section{Tartışma ve Sonuç}

Öğrenciler özyeterlik ölçeğinden en düşük 52 en yüksek ise 175 puan almışlardır. Bu öğrencilerin aldığı ortalama puan ise $145^{\prime}$ tir. Bu ortalama puana göre öğrenciler kendilerinin okuma becerisi bakımından yeterli olduğuna ilişkin yüksek düzeyde bir algıya sahip görünmektedir. Alanyazındaki benzer nitelikteki diğer bazı çalışmaların sonuçları da öğrencilerin özyeterlik algılarının yüksek olduğunu göstermektedir (İnnalı ve Aydın, 2014; Uçgun, 2014). Bunun yanında aynı ölçme aracıyla veri toplanan bir diğer çalışmada ise öğrencilerin okumaya ilişkin özyeterlik algılarının düşük olduğu bulgulanmıştır. Ölçme araçlarının aynı olmasına karşın özyeterlik algılarının farklı çıkması, aynı düzeyde ancak farklı bölgelerdeki öğrencilerin okuma bakımından kendilerini farklı yetkinlik düzeylerinde gördüğüne işaret etmektedir.

Böyle bir durumda öğrencilerin özyeterlik algılarına ilişkin ortaya çıkan bu görünümün okuma-anlama ile ilişkisi okuma-anlama ve okur özyeterliği arasında bir ilişkinin olup olmadığını ortaya koyabilmek açısından önemli görünmektedir. Türkçe alanyazındaki araştırmaların çoğu ortaokul öğrencilerinin okur özyeterlik algılarıyla okuma-anlama puanları arasında anlamlı bir ilişki olduğunu ortaya koymaktadır. Buna göre özyeterlik algısı yüksek olan öğrencilerin okuma-anlama puanları da yüksek iken okur özyeterlik algıları düşük olan öğrencilerin okuma-anlama puanları ise düşüktür (Altunkaya, 2018; İnnalı ve Aydın, 2014; Uçgun, 2014). Tarafimızdan yapılan çalışmanın sonuçları da benzer yöndedir. Ancak bu çalışma diğer çalışmalara göre okumayı tek boyutlu olarak ele almamaktadır. Bu çalışmada okur özyeterlik algısı ile yüzey metin kavrama ve çıkarımsal kavrama arasındaki ilişki ayrı ayrı ele alınmıştır.

$\mathrm{Bu}$ bağlamda çıkarım puanlarının ortalaması 22 puan içinden 11, yüzey metin puanlarının ortalaması ise 14 puan içinden 10'dur. Buna duruma göre öğrencilerin yüzey metin sorularını yanıtlamada daha başarılı oldukları buna karşın çıkarım sorularını yanıtlamada ise daha başarısız oldukları dikkat çekmektedir. Çıkarım sorularındaki başarı durumları ortalama düzeyde iken yüzey metin sorularındaki başarı düzeyleri daha yüksek görünmektedir. Bu kavrama boyutlarıyla okur özyeterliği arasındaki ilişkiye bakınca yukarıdaki çalışmalar benzer bir durumun varlığı söz konusu olmakla birlikte özyeterlik algısı ile yüzey metni kavrama arasında daha yüksek düzeyde bir ilişkinin var olması dikkat çekmektedir. Bu durum öğrencilerin yüzeysel kavramaya ilişkin algılarının çıkarımsal kavramaya ilişkin algılarına göre okuma-anlamayla daha yüksek düzeyde ilişkili olduğunu göstermektedir. Bu sonuç bir yönüyle de öğrencilerin okumayı daha çok yüzeysel anlama ile ilişkilendirebildiklerine, çıkarım boyutuna ilişkin kendileri hakkında çok farkındalıklarının olmadığına da gönderimde bulunmaktadır.

Oakhill (1984), yapmış olduğu çalışmada çıkarım gerektiren soruların diğer sorulara göre daha zor yanıtlandığını ortaya koymuştur. Dolayısıyla yetkin olmayan okur çıkarım gerektiren soruları yanıtlamakta yetersiz kalmaktadır. Çünkü çıkarım sorularını yanıtlamak 
metinde açıkça verilen bilginin ötesine geçmek, var olan bilgileri metindeki bilgiler aracılığıyla yorumlamak, metindeki farklı tümceler ve düşünceler arasında yeni bağlantılar kurmak gibi daha ileri düzeyde bilişsel işlemler yapmayı gerektirmektedir. Ortaokul öğrencilerinin hem bu denli karmaşık bilişsel işlemlerin farkında olması hem de bu işlemleri yapıp yapamadıklarına ilişkin doğru bir algıya sahip olmaları zordur. Bu bakımdan özyeterlik algısının çıkarım gerektiren sorularla ilişkisinin daha düşük olarak çıkması beklenen bir durumdur. Diğer yandan ise özyeterlik algısının yüzey metin sorularını yanıtlama ile daha yüksek düzeyde bir ilişkiye sahip olması bir bakıma bu tür soruları yanıtlayabilmek için çıkarım sorularını yanıtlamaya göre daha az bilişsel işlem yapmanın gerekli olmasıyla da açıklanabilir.

Türkçe alanyazında yer alan bir diğer çalışma olarak Ürün Karahan (2017) tarafindan yapılan çalışmada ise öz yeterlik algılarının okuduğunu anlamayla arasında anlamlı bir ilişki olmadığı saptanmıştır. Ancak bu çalışma Türkçe öğretmeni adayları ile yapılmış bir çalışma olması bakımından diğer çalışmalardan ve tarafımızdan yapılmış olan bu çalışmadan ayrılmaktadır. Türkçe alanyazındaki az sayıdaki çalışmanın sunduğu görünüme bakılınca karşımıza şöyle bir görüntü çıkmaktadır. Ortaokul öğrencilerinin okur özyeterlik algıları ile okuma-anlama puanları arasında bir ilişkinin olduğu dikkat çekerken üniversite öğrencilerinin okur özyeterlik algıları ile okuma-anlama puanları arasında bir ilişkinin olmadığı dikkat çekmektedir. Yeni bir sonuç olarak da okuma-anlama ile özyeterlik arasındaki ilişki yüzey metni kavrama boyutunda daha yüksek iken çıkarım boyutunda daha düşüktür. Yabancı alanyazında yer alan çalışmaların bulguları da birbiriyle çok tutarlı görünmemektedir (Carol ve Fox, 2017; Solheim, 2011). Dolaysıyla birçok değişkeni dikkate alan daha çok sayıda araştırmaya duyulan gereksinim de açıtır. 


\section{Kaynakça}

Altunkaya, H. (2018). Ortaokul 8. sınıf öğrencilerinin okur özyeterlikleri ile okuduklarını anlama becerileri arasındaki ilişki. Ana Dili Eğitimi Dergisi, 6 (1), 202-219.

Bandura, A. (1993). Perceived self-efficacy in cognitive development and functioning. Educational Psychologist, 28 (2), 117-148.

Caccamise, D., Snyder, L., \& Kintsch, E. (2008). Constructivist theory and the situation model relevance to future assessment of reading comprehension. In comprehension instruction research-based best practices, (Eds.) Cathy Collins Block, Sheri R. Parris, New York: The Gulford Press.

Corkett, J., Hatt, B., \& Benevides, T. (2011). Student and teacher selfefficacy and the connection to reading and writing. Canadian Journal of Education, 34, 65-98.

Epçapan, C. ve Demirel, Ö. (2011). Okuduğunu anlama özyeterlik ölçeğinin geçerlik ve güvenirlik çalışması. Uluslar arası Sosyal Araştırmalar Dergisi, 4 (16), 120-128.

Erdem, İ., Altunkaya, H. ve Ateş, A. (2017). Türkçeyi yabancı dil olarak öğrenenlerin okur özyeterlikleri ile okuduğunu anlama becerileri arasındaki ilişki. International Journal of Language Academy, 5 (4), 74-86.

Eyüp, B. ve Uzuner Yurt, S. (2016). Ortaokul öğrencilerinin okuma tutumları ve okuduğunu anlama öz yeterlikleri arasındaki ilişki. Akademik Araştırmalar Dergisi, 67, 201-216.

Ghabdian, F., \& Ghafournia, N. (2016). The relationship between Iranian EFL learners' self- efficacy beliefs and reading comprehension ability. English Linguistics Research, 5 (1), 38-50.

Ghonsooly, B., \& Elahi, M. (2010). Learners' self-efficacy in reading and its relation to foreign language reading anxiety and reading achievement. Journal of English Language Teaching and Learning, 53 (217), 45-63.

Guthrie, J. T., Hoa, A. L. W., Wigfield, A., Tonks, S. M., Humenick, N. M., \& Littles, E. (2007). Reading motivation and reading comprehension growth in the later elementary years. Contemporary Educational Psychology, 32, 282-313.

İnnalı, H., Ö. ve Aydın, İ. S. (2014). İlköğretim 8. sınıf öğrencilerinin okur öz yeterliklerinin çeşitli değişkenlere göre incelenmesi. Turkish Studies - International Periodical For The Languages, Literature and History of Turkish or Turkic Volume 9 (9), 651-682.

James W. Chapman \& William E. Tunmer (2003). Readıng difficultıes, readıng-related self-perceptions, and strategies for overcomıng negative selfbeliefs. Reading \& Writing Quarterly, 19 (1), 5-24.

Karabay, A. (2013). Eleştirel okuma öz yeterlik algı ölçeğinin geliştirilmesi. Turkish Studies International Periodical For The Languages, Literature and History of Turkish or Turkic , 8 (13), 1107-1122.

Kanadlı, S. ve Bağçeci, B. (2015). Öğrencilerin İngilizce öz yeterlik inançlarının algılanan özerklik desteği açısından incelenmesi. Mustafa Kemal Üniversitesi Sosyal Bilimler Enstitüsü Dergisi, 12 (30), 98-112.

Mills, N., A., Pajares, F., \& Herron, C. (2006). A reevaluation of the role of anxiety: Self-efficacy, anxiety and their relation to reading and listening proficiency. Foreign Language Annals, 39 (2), 273-292.

Mucherah, W., \& Yoder, A. (2008). Motivation for reading and middle school students' performance on standardized testing in reading. Reading Psychology, 29, 214-235.

Naseri, F., \& Ghabanchi, Z. (2014). The relationship between self-efficacy beliefs, locus of control and reading comprehension ability of Iranian EFL advance learners. International Journal of Language Learning and Applied Linguistics World (IJLLALW), 5 (1), 156-174. 
Oakhill, J. V. (1984). Inferential and memory skills in children's comprehension of stories. British Journal of Educational Psychology, 54, 31-39.

Oakhill, J., Cain, K., \& Elbro, C. (2015). Understanding and teaching reading comprehension: a handbook. New York: Routledge.

Öztürk, K., B. (2015). Ortaokul öğrencilerinin okur öz yeterlikleri üzerine bir araştırma: Adana ili örneği. Adlyaman Üniversitesi Sosyal Bilimler Enstitüsü Dergisi, 8 (21), 909-936.

Pajares, F. (2005). Self-efficacy during childhood and adolescence implications for teachers and parents. F. Pajares \& T. Urdan (Eds.) Self-efficacy beliefs of adolescents (pp.339-367). Greenwich: Information Age Publishing.

Shell, D. F., Murphy, C. C., \& Bruning, R. H. (1989). Self-efficacy and outcome expectancy mechanisms in reading and writing achievement. Journal of Educational Psychology, 81 (1), 91-100.

Solheim, O.J. (2011) The impact of reading self-efficacy and task value on reading comprehension scores in different item formats. Reading Psychology, 32 (1), 1-27.

Schunk, D., H. (2003). Self-efficacy for reading and writing: influence of modeling, goal setting, and self-evaluation. Reading \& Writing Quarterly, 19 (2), 159-172.

Tabrizi, A., R., N., \& Jafari, M. (2015). The relationship among critical thinking, self-efficacy, and Iranian EFL learners' reading comprehension ability with different proficiency levels. Academic Research International, 6 (2), 412-427.

Tracey, D., H., \& Morrow, L., M. (2017). Sosyal Öğrenme Görünümleri, D. Yaylı (çev.), Okumaya Genel Bir Bakış içinde (Çev. Ed. H. Ülper), Ankara: Pegem Yayıncılık.

Uçgun, D. (2014). 8. sınıf öğrencilerinin okur öz yeterliklerinin incelenmesi: Niğde ili örneği. International Journal of Language Academy, 2 (2), 38-47.

Ülper, H. (2010). Okuma ve Anlamlandırma Becerilerinin Kazandırılması. Ankara: Nobel Yayınları.

Ülper, H., Çetinkaya, G. ve Bayat, N. (2017). Okuduğunu anlama testinin geliştirilmesi. Ahi Evran Üniversitesi Kırşehir Eğitim Fakültesi Dergisi (KEFAD), 18 (1), 175-187.

Ülper, H., Yaylı D. ve Karakaya İ. (2013). Okur özyeterlik ölçeğinin geliştirilmesi. Ahi Evran Üniversitesi Kırşehir Ĕ̈itim Fakültesi Dergisi (KEFAD), 14 (1), 85-100.

Ürün Karahan, B. (2017). Türkçe öğretmeni adaylarının okur öz yeterlik algılarının okuduğunu anlama düzeyleri ile ilişkisi. Okuma Yazma Eğitimi Araştırmaları, 5 (2), 65-74.

Wigfield, A., \& Guthrie, J. T. (1995). Dimensions of children's motivations for reading: An initial study (Research Rep. No. 34). Athens, GA: National Reading Research Center.

Zimmerman, B. J. (2000). Attainment of self-regulation: A social cognitive perspective, M. Boekaerts, P. R. Pintrich, and M. Zeidner (eds). in Handbook of Self-Regulation (pp. 13-39). SanDiego, CA: Academic Press 


\section{Extended Abstract}

\section{Introduction}

People who have high self-efficacy try more, don't give up early and succeed. Therefore, students' self-efficacy level influences their academic achievement. Perception of self-efficacy determining academic achievement is also in a close relationship with reading skills. Reading skills self-efficacy is a person's belief about being able to read effectively and the capacity of understanding every text. Individual whose self-efficacy is high maintains reading process in a qualified way. Reading process maintained in a qualified way increases reading ability. With increased ability of reading, individual's perception of self-efficacy will become strong. In other words, the perception of self-efficacy supports reading, reading ability, on the other hand supports the perception of self-efficacy.

Reading comprehension process is not one dimensional. For a good reading comprehension process, an individual should be able to do inferencing reporting as well as surface text reporting. Superficial reporting requires to go beyond the information given, to interpret that information. Shortly, in order to understand a written text, cognitive reporting in different level should be done. Therefore, while searching the relationship between self-efficacy and reading comprehension, reading comprehension's relationship with different dimensions should also be taken into consideration.

Researches done abroad has studied the relationship between self-efficacy and reading comprehension frequently. This relationship has been the subject of researches in our country as well. However, researches in the literature have discussed the process of reading comprehension in one dimensional way. So, it is realized that the relationship between perception of selfefficacy and different reading dimensions has not been studied yet. For this reason, our research's purpose is to gain the research findings that is practiced on different samples within the frame of dimensional relationship between the perception of reading self-efficacy and reading comprehension skill. Contributing to deepen the literature is thought in this way.

\section{Method}

This quantification study is a research aiming to define the relationship between 8th grade students' perception of reading self-efficacy and reading comprehension levels. Research has been done with 1033 students (girls=537, boys=496) who were chosen by random sampling in the city of Antalya and its counties in 2017-2018 Academic Year. Socioeconomic levels of schools in the research have been defined, too.

Necessary permissions have been got from Antalya Directorate of National Education and data has been gathered after these permissions. Data has been gathered by the help of two different assessment instruments. The first practiced one is Reading-Comprehension Test improved by Ülper, Çetinkaya and Bayat (2016). About two weeks later, Reader Self-Efficacy Scale improved by Ülper, Yaylı and Karakaya (2013) has been practiced. All data gathered has been loaded to SPSS 22 Program and in the process of data, Spearman's Rank Correlation Coefficient has been calculated. 


\section{Findings}

In the research, when 8th grade students' points are analyzed, it is observed that their perception of self-efficacy level is high. The highest point that can be got by students from the inference questions is 22 . When looked at the research data, the average of students' inference points is 11. This situation shows that students are intermediate in answering the inference questions. The highest point that can be got by the students from the surface text questions is 14. Data of research shows that surface text points average is 10 . According to this situation, it is seen that students are more successful in answering the surface text questions.

Correlation between the perception of self-efficacy and the ability of answering surface text and inference questions was found significant at 0,01 level. Correlation between the perception of self-efficacy and answering inference questions was found at .261 level. This is the sign of a low level correlation. However, correlation between the perception of self-efficacy and answering surface text questions was found as .352. This situation shows the existence of a medium level relation.

\section{Discussion}

Students' average point from the self-efficacy scale is 145 out of 180 .According to this average, students have a high perception about their ability of reading. Similar studies' results at the literature show that their perception of self-efficacy is high as well. Moreover, in a different study that data was gathered with the same assessment instrument, it was found that students' perception of self-efficacy about reading was low. This situation is the sign of the fact that students from different regions see themselves at different levels about reading. But in this study, reading is not handled as one dimensional like other studies. In this study, correlation between perception of reader's self-efficacy and surface text comprehension and inferencing comprehension have been researched individually.

The average of inference points is 11 out of 22 and the average of surface text points is 10 out of 14. Accordingly, success in the inference questions is at the medium level. Also it was defined that success in the surface text questions was higher. It was observed that students were successful in the surface text questions while their success was falling in the inference questions. This situation shows that students' perception of surface comprehension is at the higher level than the perception of inferencing comprehension. This result also refers that students could correlate reading with surface comprehension more and they didn't have the awareness about themselves at the dimension of inference. When the literature is studied, it is seen that neither in our country nor in other countries, the results of the research are consistent. It is obvious that more researches which take a lot of factors into consideration are needed. 